OPEN ACCESS

Edited by:

Raju Datla

National Research Council Canada (NRC-CNRC), Canada

Reviewed by:

Barry J. Shelp,

University of Guelph, Canada

Michael A. Grusak,

Edward T. Schafer Agricultural

Research Center, United States

${ }^{*}$ Correspondence:

Daniel P. Roberts

dan.roberts@usda.gov

Autar K. Mattoo

autar.mattoo@usda.gov

tThese authors have contributed equally to this work

Specialty section:

This article was submitted to Crop Biology and Sustainability, a section of the journal Frontiers in Sustainable Food Systems

Received: 02 June 2019

Accepted: 20 August 2019

Published: 04 September 2019

Citation:

Roberts DP and Mattoo AK (2019) Sustainable Crop Production Systems and Human Nutrition.

Front. Sustain. Food Syst. 3:72 doi: 10.3389/fsufs.2019.00072

\section{Sustainable Crop Production Systems and Human Nutrition}

\author{
Daniel P. Roberts ${ }^{*+}$ and Autar K. Mattoo ${ }^{*+}$ \\ Sustainable Agricultural Systems Laboratory, Agricultural Research Service, United States Department of Agriculture, \\ Beltsville, MD, United States
}

There is a pressing need for redesigning agriculture to achieve sustainability and for utilizing modern genetic tools, including genetic engineering, to add nutritional value to crops for the benefit of the diverse human population. Collectively, plant foods contain most minerals, macronutrients (calories), and micronutrients essential for human nutrition. These plant foods also contain a range of bioactive compounds that can play important roles in the prevention of chronic diseases including heart disease, cancer, stroke, diabetes, Alzheimer's, cataracts, and age-related functional decline. However, these bioactive nutrients are often present at marginal concentrations in edible plant tissues in regard to human nutrition/prevention of disease. The quantity of these nutrients in edible plant tissues is primarily dependent on crop genetics and regulated by complex and overlapping mechanisms in response to developmental and environmental cues. Environmental cues are naturally occurring-temperature, light intensity, and other stressors, or result from crop production system components-fertilizer, tillage operations, etc. One strategy for sustainable, next-generation crop development is to design cropping systems that have minimal or lesser impact on the environment and to use genetic approaches to enhance crop nutritional content. This strategy is appealing since crop genetics is the primary driver of plant nutrient content and because purely managing crop production fields to optimize crop nutrient content is extremely challenging if not impossible. As an example we present the development of a next-generation sustainable tomato production system with beneficial impacts on tomato physiology and nutritional quality of the tomato fruit. Our analysis of the metabolomes of tomato cultivars in this and other cropping systems highlights the need for robust cultivars that consistently express nutritional and other desirable traits across cropping systems and under differing environmental conditions.

Keywords: human nutrition, sustainable agriculture, crop production system, vitamins, minerals, phytochemicals

\section{INTRODUCTION}

The increasing human population confronts agriculture with unprecedented challenges. More food of higher nutritional content will be needed to feed the anticipated world population of 8-10 billion by 2050 (Foley et al., 2011; Martin, 2013; Mattoo, 2014; Martin and Li, 2017). This is particularly challenging given a decline in crop yields and increasing water shortages in many regions of the world (Rosegrant and Cline, 2003). Crop production systems need to be modified to decrease the impact of crop production on the environment and for sustaining heightened levels of food 
production (Roberts and Mattoo, 2018). Additionally, there is a need to change the way we develop crop cultivars, and to focus on novel crop cultivar development if we are to meet these food production and quality challenges. The agricultural industry needs to strive toward meeting the nutritional needs of the human population and toward protecting the soil, water, and air needed to produce nutritious food.

In the past, development of crop production systems focused on maximizing yield through use of irrigation, synthetic fertilizer, and synthetic pesticides (Triplett and Dick, 2008; Reganold and Wachter, 2016; Roberts and Mattoo, 2018). Such strategies increased crop yield but often led to soil erosion, decreased soil fertility, and negative impacts on ground water, lakes, rivers, and coastal ecosystems (Matson et al., 1997; Tilman et al., 2001; Foley et al., 2011). More sustainable cropping systems for crop production are being developed to protect and improve soil and water resources. These next-generation cropping systems focus on building soil health and minimizing inputs of synthetic fertilizers, pesticides, and water (Mattoo and Teasdale, 2010; Fatima et al., 2016; Roberts and Mattoo, 2018).

More recent efforts for increasing cropping system sustainability have involved the use of cover crops and other biologicals (Mattoo and Teasdale, 2010; Roberts and Mattoo, 2018). Cover crops are non-cash crops used for a variety of ecosystem services including enhancement of soil nitrogen fertility, soil carbon, water infiltration, and weed control as well as prevention of soil erosion and controlling plant disease (Mattoo and Teasdale, 2010). Biologicals such as plant-beneficial microbes are being used for plant disease control, plant growth promotion, and as biological fertilizers to enhance availability of nutrients such as nitrogen, and phosphate to plants (Finkel et al., 2017; Backer et al., 2018). Other efforts include reducing tillage to build soil health and decreasing inputs of synthetic fertilizers and pesticides through big-data driven precision agriculture (Gebbers and Adamchuk, 2010; Mattoo and Teasdale, 2010; Balafoutis et al., 2017; Roberts and Mattoo, 2018; Weersink et al., 2018). A growing body of evidence indicates that crop management strategies can impact crop nutritional quality (Zhu et al., 2007; Hirschi, 2009; Fatima et al., 2016; Vasconcelos et al., 2017). As we develop new sustainable crop production systems, we must also pay attention to their impact on crop physiology as well as crop nutritional content, in order to develop future environmentally friendly cropping systems that also increase nutritional quality of food wherever possible.

The primary focus of past crop breeding strategies has been to increase yield of calorie-rich food crops. For example, prior breeding programs focused on increasing disease resistance, fruit set and size, and grain fill (Grusak and DellaPenna, 1999; Borlaug, 2000; Lei et al., 2007; Wang et al., 2008; Kyriacou and Rouphael, 2018). Such crop cultivars contained calorie-rich macronutrients such as fat, protein, and carbohydrate but not necessarily adequate vitamins, minerals, and other phytochemicals to meet human nutritional needs. Today there is a need to expand crop cultivar development so that both yield and nutritional quality are maximized, together with resistance to biotic and abiotic stresses, and efficient water and soil nutrient use (Martin, 2013; Mattoo, 2014; Martin and Li, 2017).
Herein, we present background information on human nutrition, essential metabolic pathways, and impact of cropping system management on nutritional quality of food. We also highlight an example of a sustainable next-generation tomato production system and its impact on tomato physiology and nutritional attributes of tomato fruit.

\section{PLANT-DERIVED NUTRIENTS FOR HUMAN NUTRITION AND MAINTENANCE OF HUMAN HEALTH}

Plants are an integral part of the human diet and provide a good dose of minerals required for human nutrition (Graham et al., 2001). They also are a good source of energyproviding macronutrients: carbohydrate, protein, and lipids. The micronutrients for human health include: vitamins $\mathrm{A}, \mathrm{B}$ complex, C, E, and K; essential lipids; and essential amino acids, which in plants are variable in amount and, in instances, insufficient to provide a nutritional dose. These vitamins cannot be synthesized by humans and must be obtained from dietary sources. The essential fatty acids, linoleic acid, and linolenic acid, also cannot be synthesized by humans (Grusak and DellaPenna, 1999; Martin and Li, 2017). Likewise, the amino acids histidine, isoleucine, leucine, lysine, methionine, phenylalanine, threonine, tryptophan, and valine must be obtained from ingested protein in dietary sources. Insufficient quantities of these essential micronutrients and minerals in the diet can have long-term negative impacts on human health and lead to classical micronutrient deficiency diseases (Grusak and DellaPenna, 1999; White and Broadley, 2009; Oliver and Gregory, 2015; DíazGómez et al., 2017; Vasconcelos et al., 2017).

Fruits and vegetables provide beneficial phytonutrients that are bioactive but not sufficient to positively and globally impact human health. These phytonutrients show promise in protection against many diseases (Grusak and DellaPenna, 1999; Martin and Li, 2017). Correlations exist between increased consumption of phytonutrients and decreased chronic diseases such as heart disease, stroke, diabetes, Alzheimer's, cataracts, and age-related functional decline (Martin et al., 2011; Liu, 2013; Martin, 2013; Martin and Li, 2017). Data on health benefits of these phytonutrients is largely epidemiological but persuasive (Grusak and DellaPenna, 1999; Liu, 2013; Martin, 2013). The most important groups of these phytochemicals are phenolics (phenolic acids, flavonoids, stilbenes, coumarins, tannins), alkaloids, organosulfur compounds, phytosterols, and carotenoids (Liu, 2013; Martin and Li, 2017).

For maintenance of good human health, a complex diet consisting of a high dose of several plant foods is necessary. However, plants and plant parts vary in quantity and quality of these vitamins and minerals, and all major food crops lack certain essential micronutrients (Grusak and DellaPenna, 1999; Zhu et al., 2007; Hirschi, 2009; Martin and Li, 2017). For example, rice, wheat, and maize, major food crops worldwide, are calorierich but contain levels of several micronutrients insufficient to meet human minimum daily requirements (Hirschi, 2009). The endosperm of these cereal staples-rice, wheat, and maize, provide 
$\sim 23,17$, and $10 \%$ of total calories for humans globally. Moreover, endosperm tissue lacks sufficient vitamins (particularly vitamins $\mathrm{A}, \mathrm{C}, \mathrm{E}$, and the B vitamin folate), and minerals (particularly Fe, Zn, and Se) (Zhu et al., 2007; Goméz-Galera et al., 2010; Rawat et al., 2013). Seed foods are sources of macronutrients and lipid-soluble vitamins but tend to have low concentrations of $\mathrm{Fe}$ and $\mathrm{Ca}$. Leafy vegetables are sources of most minerals and some vitamins but are less nutrient dense in macronutrients protein and carbohydrate. On the other hand, fruits are a resource of carbohydrate and water-soluble vitamins but minimally provide protein and minerals (Grusak and DellaPenna, 1999). Most plant crops are also limiting in one or more essential amino acids for the human diet (Wang et al., 2003; Hirschi, 2009).

\section{Carotenoids, Provitamin A and Plants}

Plants synthesize different carotenoids that have functional roles in growth processes as well as in providing defense against extreme environments. Plant carotenoids are also central to the human diet for providing provitamin A and carotenoids. Humans generate vitamin A from carotenoids containing at least one $\beta$-ionone ring (e.g., $\beta$-carotene, $\alpha$-carotene, $\beta$ cryptoxanthin). Carotenoids are synthesized in whole or in part from the plastidic isoprenoid biosynthetic pathway and comprise a large family consisting mostly of $\mathrm{C}_{40}$ tetraterpenoids derived from phytoene (DellaPenna and Pogson, 2006). Plants cope with their environment through multiple important roles of carotenoids, for instance in photosynthesis as components of the photosystem assembly, increasing photosynthetic efficiency, thereby extending the range of wavelengths absorbed (Frank and Cogdell, 1996; DellaPenna and Pogson, 2006; Fanciullino et al., 2013). Certain carotenoids, such as $\beta$-carotene, play a photoprotective role in photosynthesis by quenching excited chlorophyll molecules and as protectors of the photosynthetic machinery through scavenging of oxygen radicals (Mozzo et al., 2008; Gracía Plazaola et al., 2012). Carotenoids play roles in plant-environment interactions; as general antioxidants, believed to protect membrane surfaces from hydrophilic oxidants; and as intermediates in the synthesis of plant hormones such as abscisic acid and strigolactones involved in plant adaptation to abiotic stress (Rolland et al., 2012; Fanciullino et al., 2013). Also, the carotenoids lycopene and $\beta$-carotene serve as visual cues attracting pollinators and seed dispersers after they accumulate in flowers and fruits (DellaPenna and Pogson, 2006; Fanciullino et al., 2013; Esteban et al., 2015).

Not surprisingly, due to these roles of carotenoids in plant metabolism, carotenoid biosynthesis is under developmental control and influenced by a variety of environmental conditions (Liu et al., 2015b). For example, carotenoid biosynthesis is tightly coordinated with plastid development and differentiation of fruit. During tomato fruit ripening, total carotenoid concentration increases more than 15-fold, mainly due to lycopene accumulation (Fraser et al., 1994). Carotenoids also increase during the development process of pepper and citrus fruit (Hugueney et al., 1996; Kato et al., 2004). It is thought that the increase in carotenoid concentration and resultant color change of the fruit is a signal directed at seed dispersers when seeds are ready for dissemination
(Fanciullino et al., 2013). Consistent with the antioxidant role of carotenoids, key regulatory points in the carotenoid biosynthetic pathway are sensitive to environmental conditions. Phytoene synthase is a key regulatory enzyme in the synthesis of phytoene, a condensation product of two molecules of geranylgeranyl pyrophosphate. Phytoene synthase activity is impacted by abiotic factors such as high light, salinity, $\mathrm{CO}_{2}$, drought, photoperiod, and salt. A second key regulatory point is downstream in the carotenoid biosynthetic pathway where the bifurcation between cyclization of lycopene toward the $\alpha$ - or the $\beta$-carotene pathways occurs. Under low light conditions, selective accumulation of $\alpha$-carotene derivatives occur while under high light $\beta$-carotene derivatives accumulate (Esteban et al., 2015).

\section{B Vitamins}

$B$ vitamins are a set of eight water-soluble vitamins that function as enzyme cofactors, or their precursors, for enzymes that function in core metabolic processes. These enzyme cofactors complement the innate chemistry provided by enzyme's amino acid functional groups (Roje, 2007; Smith et al., 2007; Gerdes et al., 2012). All B vitamins except cobalamin (B12) are synthesized by plants. There is evidence that thiamine (B1) and riboflavin (B2) protect plants from pathogen infection, and that vitamin B6 (pyridoxine) contributes to their photoprotection as well as tolerance to osmotic and oxidative stresses (Roje, 2007). Synthesis of some of these B vitamins is developmentally regulated and subject to environmental signals (Smith et al., 2007). For example, thi1 in Arabidopsis, a gene functioning in the synthesis of thiamin, is developmentally regulated and regulated by light. Expression of thi1 is also influenced by stress conditions, including high salinity and sugar deprivation (Hanson et al., 2016).

\section{Vitamin E}

Tocochromanols are lipid soluble antioxidants essential to human nutrition as vitamin E. These compounds are composed of a hydrophobic polyprenyl side chain synthesized from the plant plastidic isoprenoid biosynthetic pathway and a polar chromanol ring derived from the shikimate pathway. Tocopherols $(\alpha, \beta, \gamma, \delta)$ are tocochromanols with phytylderived side chains while tocotrienols $(\alpha, \beta, \gamma, \delta)$ have geranylgeranyl-derived side chains. The various forms $(\alpha$, $\beta, \gamma, \delta$ ) of tocopherols and tocotrienols vary only in the degree of methylation of the respective polyprenyl side chain (Mène-Saffrané and DellaPenna, 2010). The two major tocopherols found in plants are $\alpha$ - and $\gamma$-tocopherol with $\alpha$-tocopherol being the primary form found in green leaves and $\gamma$-tocopherol the primary form in seeds, fruits, and nuts (Lushchak and Semchuk, 2012). Tocotrienols are present at significant levels in monocot seeds but not in photosynthetic tissue (Mène-Saffrané and DellaPenna, 2010). Tocochromanols are strong antioxidants that protect polyunsaturated fatty acids from lipid peroxidation. Enrichment of $\alpha$-tocopherol in chloroplast membranes protects the photosynthetic apparatus from oxidation and lipid peroxidation due to its ability to 
scavenge singlet oxygen and lipid peroxyl radicals (MèneSaffrané and DellaPenna, 2010; Lushchak and Semchuk, 2012).

Like carotenoids and B vitamins, tocochromanol biosynthesis changes during plant development and is impacted by environmental stressors (Mène-Saffrané and DellaPenna, 2010; Lushchak and Semchuk, 2012). For example, tocopherol levels are known to change during leaf development and increases during aging. Environmental stressors such as high light intensity, low temperature, drought, high salinity, and heavy metal ions increase tocopherol levels in plants (Poiroux-Gonord et al., 2010; Lushchak and Semchuk, 2012).

\section{Vitamins $\mathbf{C}$ and $\mathrm{K}$}

Ascorbate (vitamin C) is the predominant antioxidant in plant cells, found in all subcellular compartments including the plant apoplast. Ascorbate can be oxidized by oxygen, superoxide, singlet oxygen, and hydrogen peroxide to the monodehydroascorbate (MDHA) radical (Smirnoff, 2000) detoxifying these compounds. Ascorbic acid is also a cofactor for many enzymes, notably ascorbate peroxidase (Smith et al., 2007). Like other vitamins, ascorbate biosynthesis is responsive to light intensity and highly sensitive to environmental stress. Vitamin $K_{1}$ (phylloquinone) is an essential component of electron transport in photosystem I. It is present in leaves, and to a lesser extent in certain seeds. Vitamin $\mathrm{K}_{1}$ has antioxidant properties but its role in plant antioxidant defense remains to be determined (Asensi-Fabado and Munné-Bosch, 2010).

\section{Phenolics}

Phenolic compounds play important structural roles in plants, providing most of the mechanical strength of cell walls. Moreover, a diverse array of plant phenolics has important roles in plant growth and survival (Cheynier et al., 2013; Liu et al., 2015a). Synthesis of phenolics is catalyzed by phenylalanine ammonia lyase, cinnamate 4-hydroxylase, and p-coumaroyl coenzyme A ligase, referred to as the general phenylpropanoid pathway. Phenolic compounds include the structurally diverse monolignols, flavonoids (anthocyanins, proanthocyanidins, flavonols, flavones, flavanones, isoflavonoids, phlobaphenes), various phenolic acids, and stilbenes. This enormous array of secondary metabolites is generated from a few core intermediates via the activity of a combination of reductases, oxygenases, and transferases (Vogt, 2010; Liu et al., 2015a).

Monolignols function as precursors to lignin, a heteropolymer derived from the monolignols p-coumaryl, conferyl, and sinapyl alcohols. Lignin provides much of the mechanical strength of plants but also provides protection against wounding, pathogen attack, and UV light. Flavonoids function as pigments in flowers and fruits to attract pollinators and seed disseminators. They are also involved in regulation of auxin transport, signaling (such as nodule formation in legumes), determination of male fertility, and defense against biotic and abiotic stress. Flavonoids accumulate in leaf epidermal cells, waxes, and trichomes, where they act as protectants against UV light and complex with DNA for protection against oxidative damage. Phenolic acids are highly antioxidative and several are known to be active against microbes. The phenolic acid, salicylic acid, plays an important role in signaling/activating systemic plant defense responses. Stilbenes are produced in response to pathogen attack, wounding, and exposure to UV light (Hichri et al., 2011; Davies et al., 2012; Liu et al., 2015a). In general, plant phenolics contribute to plant defense against biotic stress, can accumulate in response to pathogen attack, and most exhibit antimicrobial and pesticidal properties (Dixon et al., 2002; Chong et al., 2009). Accumulation of phenolic compounds contributes to a general reduction of reactive oxygen species (ROS), protecting plant processes sensitive to redox effects (Cheynier et al., 2013).

As with vitamins and carotenoids, regulation of phenolic biosynthesis involves a matrix of potentially overlapping regulatory signals. For instance, phenolic biosynthesis is responsive to developmental signals for lignification of plant tissues, for production of flavonoids during fruit and flower development; and environmental signals for protection against abiotic and biotic stresses (Cheynier et al., 2013; Roy, 2016). A number of regulatory proteins, such as MYB proteins, regulate the synthesis of phenylpropanoid metabolism-derived compounds (Liu et al., 2015a; Roy, 2016; Allan and Espley, 2018). MYB proteins have been identified in Arabidopsis, rice, maize, and soybean, as well as numerous fruits and vegetables, and shown to be involved in regulating flower development, berry ripening, and biotic and abiotic stresses (Stracke et al., 2001; Dubos et al., 2010; Cheynier et al., 2013; Roy, 2016). Studies involving several plant species provide evidence of the involvement of MYB proteins in regulation of synthesis of monolignols, anthocyanins, flavonols, proathocyanidins, and phenolic acids in response to sucrose, nitrogen, light, high and low temperature, drought stress, salt stress, biotic stress, and plant hormones (Liu et al., 2015a; Roy, 2016; Allan and Espley, 2018).

\section{Mineral Uptake and Translocation Within Plants}

The minerals $\mathrm{N}, \mathrm{P}, \mathrm{K}, \mathrm{Mg}, \mathrm{Ca}, \mathrm{S}, \mathrm{Fe}, \mathrm{Mn}, \mathrm{Zn}, \mathrm{Cu}, \mathrm{B}, \mathrm{Mo}, \mathrm{Cl}$, and $\mathrm{Ni}$ are essential for plants and must be obtained from the external environment (Grusak, 2002; Bindraban et al., 2015). These minerals are mostly mined as inorganic ions from the soil environment by the plant. Plants can also obtain $\mathrm{N}$ and $\mathrm{S}$ from amino acids and other organic molecules in soil while $\mathrm{P}$, available to plants as phosphate, can be obtained from organic sources such as nucleic acids, nucleotides, and phospholipids (Grusak, 2002). Most minerals enter cells as inorganic ions via protein transport systems to get across the hydrophobic cell membrane. Transport systems consisting of high and low affinity transport proteins and permeable ion channels into the cell are known (Hell and Hillebrand, 2001; Palmgren et al., 2008; White and Broadley, 2009). Once within the root symplast, long-distance mineral transport in the plant is via the xylem. Complex and intricately regulated processes are used by the plant to make these minerals available in soil for uptake, transportation into the root, distribution throughout the plant, and maintenance within cells at physiologically required concentrations (Hell and Hillebrand, 2001; Grusak, 2002; White and Broadley, 2009; Dimpka and Bindraban, 2016). As with plant vitamins and phytonutrients, 
there are significant impacts of environmental conditions on plant mineral content (Hell and Hillebrand, 2001; Palmgren et al., 2008; White and Broadley, 2009).

\section{IMPACT OF CROPPING SYSTEM MANAGEMENT ON NUTRITIONAL QUALITY OF FOOD}

\section{Plant Micronutrient Content}

The enormous number and variety of plant-derived nutrients, the variety and intricacy of regulation of biosynthesis of these nutrients, the difficulty in controlling environmental cues in production fields, and interactions among environmental cues that influence the synthesis of these nutrients, make it challenging to consistently manipulate crop nutrient content solely through current crop management techniques. Environmental factors that influence production of plant nutrients such as soil fertility, soil water availability, soil salinity, light intensity, ambient temperature, and pathogen infection are difficult to control and vary spatially within, and among production fields and temporally over growing seasons (Poiroux-Gonord et al., 2010; Roberts and Kobayashi, 2011). Even with more focus on sustainable crop production systems, it will be increasingly challenging to manage, and enhance crop nutritional quality. This is because management of biologicals such as cover crops and beneficial microbes used in more sustainable crop production systems is more challenging to manage than synthetic fertilizers and pesticides used in most current, conventional production systems (Mattoo and Teasdale, 2010; Roberts and Kobayashi, 2011).

The impacts of conventional cropping system management practices have been investigated in terms of fruit and vegetable micronutrient content (Poiroux-Gonord et al., 2010; Beauvoit et al., 2018). In general, there is no known clear-cut impact of $\mathrm{N}$ fertility on the phytonutrient levels of fruits and vegetables. The impact of $\mathrm{N}$ fertility on phytonutrient content varies across fruit and vegetable types (Crespo et al., 2010; Poiroux-Gonord et al., 2010; Lester and Saftner, 2011). Thus, positive, negative and no effects have been reported based on the amount of $\mathrm{N}$ supplied, the type of $\mathrm{N}$ supplied, the cultivar/species of crop studied, and the phytonutrient studied. As with $\mathrm{N}$ fertility, the impacts of temperature, light intensity, salinity, and drought on crop nutrient content vary with the degree of the environmental condition, cultivar/species of crop, and phytonutrient studied (Poiroux-Gonord et al., 2010; Albornoz, 2016). Other factors that impact phytonutrient content include cultivation methods, elevation of the grower field, and postharvest management (Crespo et al., 2010; Poiroux-Gonord et al., 2010; Muñoz et al., 2011; Catín et al., 2012; Manganaris et al., 2014). Differential impact of environmental conditions on different phytonutrients within the edible portions of crops further complicates and restricts manipulation of agronomic practices to enhance fruit and vegetable phytonutrient content. For example, in a greenhouse tomato study, increased fruit temperature led to increases in the level of the flavonoid rutin, while the carotenoid lycopene, and ascorbate levels were reduced (Gautier et al., 2008).
There may be unique situations, however, where crop production systems can be manipulated to enhance crop nutritional quality (Kyriacou and Rouphael, 2018; Rouphael and Kyriacou, 2018; Rouphael et al., 2018). Abiotic stress factors such as drought, salinity, and temperature extremes, cause unfavorable physiological conditions that disrupt the balance between ROS generation and ROS scavenging in plant tissues (Tripathy and Oelmüller, 2012; Das and Roychoudhury, 2014; Czarnocka and Karpinski, 2018; Foyer, 2018; Noctor et al., 2018). The net result is the induction of these phytoprotective enzyme systems together with production of more other compounds (carotenoids, tocopherols, ascorbic acid, phenolics) important for human health. Careful manipulation of certain of these plant stressors can increase phytoprotective compounds without significantly sacrificing yield of certain crops (Kyriacou and Rouphael, 2018). For example, water availability in the root zone is an agronomic factor that can be modulated to positively impact nutrient quality in certain fruit crops (Kyriacou and Rouphael, 2018). Water-saving irrigation strategies can optimize water use and impose moderate stress on deep-rooted fruit trees and vines such as apples, olives, and grapes. It is known that water deficit influences the expression of genes involved in the phenylpropanoid, isoprenoid, carotenoid, amino acid, and fatty acid metabolic pathways in grapes (Deluc et al., 2009). Thus, water deficit led to higher expression of transcripts associated with glutamate and proline biosynthesis and some committed steps of the phenylpropanoid pathway, increasing anthocyanin concentrations in Cabernet Sauvignon grape. The same condition activated parts of the phenylpropanoid, carotenoid, and isoprenoid pathways in Chardonnay grapes and contributed to increased concentrations of the carotenoid antheraxanthin, flavonols, and aroma volatiles. However, it is also known that vegetable crops are negatively impacted in yield by water deficit since they tend to be shallow rooted (Costa et al., 2007).

\section{Plant Mineral Content}

There is substantial evidence that application of inorganic micronutrient fertilizers increases the mineral levels in edible portions of crop plants with the impact of the fertilizer application dependent on the fertilization practice, the mineral, and the edible plant part studied (Hirschi, 2009; White and Broadley, 2009; Khoshgoftarmanesh et al., 2010; MartínezBallesta et al., 2010; Dimpka and Bindraban, 2016). For example, soil and foliar application of $\mathrm{Zn}$ fertilizers increase $\mathrm{Zn}$ concentrations in some plants and some soils (Shuman, 1998; Rengel et al., 1999; Cakmak, 2009; Joy et al., 2015). Fe fertilizers increase Fe concentrations in edible portions of plants (Loneragan, 1997; Shuman, 1998; Rengel et al., 1999), and Fechelates applied to soil and elemental S applied to acidify soil makes Fe more available. Foliar applications of Fe fertilizers are used, but repeated applications are necessary because $\mathrm{Fe}$ is not otherwise readily translocated within plants. Application of other micronutrient fertilizers such as those containing $\mathrm{Cu}, \mathrm{Ca}$, and $\mathrm{Mg}$ can also increase the concentration of the respective elements in plant tissues (White and Broadley, 2009; Dimpka and Bindraban, 2016). Unfortunately, these strategies may not be ideal or 
practical for other reasons as the application of fertilizers can enrich mineral levels in the environment and aquatic ecosystems, sometimes to toxic levels. Also, overfertilization with the plant macronutrient $\mathrm{N}$ can negatively impact micronutrients in crops: for example, significant reductions in Ca have been reported in tomato, cucumbers, and some fruits. Additionally, the longtime availability of mineral feedstocks needed to produce some of these micronutrient fertilizers (Hirschi, 2009; White and Broadley, 2009; Albornoz, 2016; Dimpka and Bindraban, 2016).

Sustainable crop production approaches such as legume cover crops and phosphate-solubilizing microbes, respectively, increase $\mathrm{N}$ and phosphorous in soil (Mattoo and Teasdale, 2010; Sashidhar and Podile, 2010; Shen et al., 2011). Legume cover crops capture leftover $\mathrm{N}$ in soil, fix $\mathrm{N}$ from the atmosphere, covert this $\mathrm{N}$ to biomass, and release $\mathrm{N}$ into soil upon decomposition of the cover crop (Abdul-Baki et al., 1997). Phosphate-solubilizing microbes excrete organic acids into soil, thereby decreasing soil $\mathrm{pH}$. Some phosphate-solubilizing microbes also excrete enzymes such as acid phosphatase and phytase that liberate phosphate from soil organic compounds (Cosgrove et al., 1970; Pradel and Boquet, 1988; Rodriguez and Fraga, 1999). However, the impact of these sustainable approaches on crop mineral content is not well-established.

\section{CROP GENOTYPE AND CROP NUTRIENT CONTENT}

The most important factor determining crop nutritional content is crop genotype (Lei et al., 2007; Khoshgoftarmanesh et al., 2010; Poiroux-Gonord et al., 2010; Manganaris et al., 2014; Kyriacou and Rouphael, 2018). Manipulation of crop genotype through traditional breeding approaches, as well as advanced biotechnology techniques, have been used to increase crop macro-, and micronutrient content in crops. Modern day cultivars of all major crops have diminished capabilities for uptake and incorporation of minerals or synthesis of other phytonutrients due to the almost singular emphasis of modern breeding strategies on improving crop yield (Newton et al., 2010; Rawat et al., 2013). Plant breeders have examined crop landraces and wild crop germplasm for genetic variability in phytonutrient content for use in biofortification strategies (White and Broadley, 2009; Rawat et al., 2013). These crop landraces have developed mostly in environments with low nutrient availability and represent a potential source of genetic variation for breeding for varieties adapted to poor soil nutrient status (Newton et al., 2010). Apart from traditional approaches advanced tools of biotechnology have contributed to crop improvement (Zhu et al., 2007).

A growing list of crops fortified with enhanced nutritional attributes has emerged (Mehta et al., 2002; Newell-McGloughlin, 2008; Shukla and Mattoo, 2009; Fatima et al., 2013; Zhang et al., 2015; Bouis and Saltzman, 2017; Low et al., 2017; Martin and Li, 2017; Strobbe and Van Der Straeten, 2017). Nutritional improvement strategies have led to an increase in the concentration, or quality, of the desired macronutrient or micronutrient, and compounds that enhance nutrient availability and decrease antinutrients (Bouis, 2000; Newell-McGloughlin, 2008; Khoshgoftarmanesh et al., 2010; Rawat et al., 2013). Classic examples of improving amino acid profiles in crops to meet human nutritional needs include high lysine maize, canola, and soybean cultivars via introduction of a bacterial gene that is insensitive to lysine feedback inhibition (Falco et al., 1995; Eggeling et al., 1998; O'Quinn et al., 2000). A second approach involved introduction of genes for a synthetic protein, or heterologous protein from another crop species, which elevated levels of methionine and lysine (Beauregard et al., 1995). Also, the heterologous storage protein legumin from pea, containing high levels of lysine, was introduced into rice, and wheat grains (Sindu et al., 1997; Stoger et al., 2001; Le et al., 2016). The proportions of individual fatty acids have been increased in several oilseed crops using conventional selection, mutagenesis, and tools of biotechnology (Yuan and Knauf, 1997; Zou et al., 1997; Fatima et al., 2013).

Biofortified crops have also been developed to increase delivery of vitamins and minerals in edible plant tissues. Traditional breeding strategies were used to develop orange maize and cassava with enhanced levels of provitamin A. Human consumption of orange maize effectively improves total body vitamin A stores (Bouis and Saltzman, 2017). Another good example is the orange corn with elevated zeaxanthin and leutein levels (Burt et al., 2010, 2011). Genetic engineering approaches led to large increase in $\beta$-carotene levels in rice (Zhu et al., 2007) - a strategy that utilized phytoene synthase from daffodil or maize combined with phytoene desaturase from Erwinia. Similar approaches were developed to enhance $\beta$-carotene (provitamin A) in yellow potato, orange cauliflower, and carrots (Zhu et al., 2007); other carotenoids (phytoene, lycopene, zeazanthin, lutein) in rice, potato, canola, and tomato; choline in tomato; vitamin $\mathrm{C}$ in corn and lettuce; polyphenolics (flavonol, isoflavone, resveratrol, chlorogenic acid, anthocyanin) in tomato and potato; and $\alpha$-tocopherol in soybean, lettuce and potato (Mehta et al., 2002; Butelli et al., 2008; Shukla and Mattoo, 2009; Mattoo et al., 2010; Fatima et al., 2013; Zhang et al., 2015). Crops biofortified with folate (vitamin B9) in edible plant tissues have also been developed. Sufficient genetic variation in folate levels is available in milled rice, potato, spinach, and dry bean folate to pursue traditional breeding approaches (Strobbe and Van Der Straeten, 2017). Metabolic engineering approaches have resulted in desired levels of folate in tomato fruit and rice endosperm. Introduction of a bovine folate binding protein improves folate stability in rice. Plants have also been engineered for increased concentrations of minerals such as Fe and $\mathrm{Zn}$ (Zhu et al., 2007; Bouis and Saltzman, 2017; Martin and Li, 2017). Molecular engineering also enabled reduction in the levels of the offending protein glutelin in rice, offering a new beginning for the development of super-low glutelin rice for people suffering with celiac disease.

\section{SUSTAINABLE CROPPING SYSTEM FOR TOMATO PRODUCTION}

Information about the overall impacts of sustainable production systems on crop nutrient levels is scarce; however, some of 
the component practices such as reduced tillage, crop rotation, and soil moisture management have been studied. Tillage can significantly influence yield, mostly through impacts on soil moisture, nutrient availability, soil temperature, and aeration (Wang et al., 2008). Zero tillage reduces yield and protein content of wheat and barley (Malhi and Nyborg, 1990; Malhi et al., 2001), perhaps a result of reduced $\mathrm{N}$ mineralization and increased $\mathrm{N}$ immobilization in soil (Wang et al., 2008). Rotation of cereals with grain legumes such as chickpea, lentil, and dry pea can result in increased yield and protein (Gan et al., 2003). However, there is almost no literature on the impact of biological components (cover crops, beneficial microbes) of sustainable cropping systems on crop physiology or micronutrient quality of food (Neelam et al., 2008; Mattoo and Teasdale, 2010). Impacts of plant beneficial microbes on crop gene expression and physiology have been extensively reported but these reports typically are focused on plant pathogen defense mechanisms (Van Wees et al., 2008; Pieterse et al., 2014). Our work with a sustainable, nextgeneration tomato production system indicates that impacts of these biologicals (cover crop) on crop physiology and nutrient content (fruit metabolome) can be profound (Neelam et al., 2008; Fatima et al., 2012, 2016).

\section{Sustainable, Next-Generation Tomato Production System}

Conventional, field-grown tomato production systems typically consist of raised soil beds and synthetic fertilizers, black polyethylene plastic mulch, and tillage. Synthetic fertilizer is essential to maintain $\mathrm{N}$ fertility levels while black polyethylene plastic and tillage are used to control weeds (Abdul-Baki et al., 1996). Some growers apply excess $\mathrm{N}$ to maximize yield as $\mathrm{N}$ recovery by the tomato plant from synthetic fertilizer is low, potentially contributing to surface, and groundwater pollution (Abdul-Baki et al., 1996). To increase sustainability of fieldgrown tomato production, a hairy vetch cover crop production system was developed to reduce the need for synthetic fertilizer inputs such as $\mathrm{N}$, reduce soil erosion, and increase soil water holding capacity (Abdul-Baki and Teasdale, 1993). The use of black polyethylene plastic was omitted. In this production system, the legume is planted into raised soil beds in the fall, then in early spring hairy vetch is sprayed a light herbicide dose, and finally tomato seedlings planted with no-till into the killed hairy vetch mulch. Notably, tomato yield, and economic return are typically greater with this hairy vetch production system than the conventional tomato production system (Kelly et al., 1995; Abdul-Baki et al., 1996).

One advantage of this sustainable tomato production system is reduction in requirements for synthetic fertilizer $\mathrm{N}$ input. Minimum $\mathrm{N}$ fertilizer rates necessary to achieve maximum tomato yield are reduced to $80 \mathrm{lb} /$ acre compared to $170 \mathrm{lb} /$ acre associated with the conventional black plastic system (AbdulBaki et al., 1997). Soil erosion and water runoff are also reduced. Additionally, pesticide loads released from fields are substantially reduced (Rice et al., 2001, 2002). Further, the sustainable tomato production system reduces the need for fungicide application because development of tomato early blight disease caused by
Alternaria solani is delayed (Mills et al., 2002a,b). There is also greater resistance of the crop to invasion and damage by the Colorado Potato Beetle (Teasdale et al., 2004). The results for weed competition and herbicide use were mixed.

\section{Impact of Next-Generation Tomato Production System on Tomato Physiology}

The broader impact of the no-till hairy vetch cropping system on tomato plant physiology is clear. In field and greenhouse experiments, gene transcripts and proteins involved in diverse biological processes are differentially up-regulated in leaves of hairy vetch-grown tomato plants relative to control plants grown with black plastic (Kumar et al., 2004, 2005; Mattoo and Abdul-Baki, 2006). Up-regulated genes include ribulose bisphosphate carboxylase/oxygenase (Rubisco), important for carbon fixation; nitrogen-responsive glutamate synthase, regulating carbon/nitrogen signaling; nitrogen utilizing and nitrite toxicity reducing nitrite reductase; stress-defense related protein glucose-6-phosphate dehydrogenase; chaperone proteins (HSP70 and ER protein $\mathrm{BiP}$ ) that stabilize native proteins; cytokinin- and gibberellin-related regulatory proteins; and plant defense anti-fungal proteins chitinase and osmotin. Up-regulation of these plant defense genes may increase disease resistance of the tomato crop (Mills et al., 2002a,b; Kumar et al., 2004). Other genes/proteins that promote senescence and aging, the ethylene biosynthesis gene ACC synthase and the senescenceregulated SAG12 gene, are more down-regulated in leaves from hairy vetch-grown tomato than those grown with black plastic. Consistent with this, hairy vetch-grown tomato has higher levels of the cytokinin indicator gene, cytokinin receptor protein kinase (CRK) (Papon et al., 2002; Kumar et al., 2004), together with upregulation of defense-related genes including basic chitinase (Memelink et al., 1987), and osmotin (Thomas et al., 1995). The delayed senescence is likely due to a continued supply of cytokinin from the roots to the upper parts of the plant (Noh and Amasino, 1999).

To determine if the $\mathrm{N}$ released from decomposing hairy vetch impacts the physiology of hairy vetch-grown tomato has also been investigated in a field pot experiment (Fatima et al., 2012). Tomato plants were grown either in soil taken from fields where hairy vetch had been previously grown (as the winter cover crop) and soil surface supplemented with vetch residue, or in bare soil without any hairy vetch residue. In addition, the bare soil and hairy vetch treatments were supplemented with varying amounts of inorganic $\mathrm{N}$ fertilizer. The plants grown with the hairy vetch residue produced higher tomato fruit yield, biomass, and photosynthesis compared to plants grown in bare soil. Total average tomato fruit yield in the absence of supplemental $\mathrm{N}$ was $213 \mathrm{~g}$ plant $^{-1}$ and $1,108 \mathrm{~g} \mathrm{plant}^{-1}$ for bare soil and soil plus hairy vetch, respectively (Fatima et al., 2012). Importantly, a parabolic response is evident for tomato growth and photosynthesis in response to inorganic $\mathrm{N}$ in the bare soil treatments, which suggests $\mathrm{N}$ toxicity in pots with the highest rates of supplemental $\mathrm{N}$. Notably, the parabolic response to supplemental inorganic $\mathrm{N}$ is mitigated in the hairy vetch-grown plants, where higher photosynthetic rates are maintained even at 
high supplemental inorganic $\mathrm{N}$ application rates. Further, hairy vetch also mitigated the decline in the expression of nitrogen and carbon metabolism genes (Fatima et al., 2012). These findings suggest that physiological cues released from the decomposing cover crop, other than $\mathrm{N}$, have beneficial impacts on tomato plants. The source and composition of $\mathrm{N}$ fertilizer influences gene expression in tomato and other crops (Lu et al., 2005; Mattoo and Handa, 2008; Neelam et al., 2008). Thus, N management with hairy vetch in sustainable cropping systems offers added advantages over cropping systems utilizing synthetic $\mathrm{N}$ fertilizer (Fatima et al., 2012).

\section{Impact of Agroecosystem and Crop Genotype on the Tomato Metabolome}

The agroecosystem environment discussed above also impacts the metabolome of transgenic tomato lines that were constructed to vary in the abundance of the plant growth regulators ethylene, methyl jasmonate, and polyamines (spermidine, spermine) (Fatima et al., 2016). The metabolites central to primary metabolism were analyzed for the second moment (covariances) networks (Fukushima et al., 2011) and depicted changes in correlations of paired metabolites (Fatima et al., 2016). These metabolite relationships in the tomato fruit metabolome were genotype (hormone) and environment specific, suggesting that the fruit primary metabolome is highly plastic in nature (Fatima et al., 2016). It is not surprising that modification of the agroecosystem impacts the fruit metabolome. Black plastic used in the conventional tomato cropping system results in higher soil temperature and stimulates growth and fruit development. The hairy vetch cropping system has relatively lower soil temperatures, different $\mathrm{N}$ fertility, and an altered soil microbial community (Teasdale and Abdul-Baki, 1997; Buyer et al., 2010). Consistent with these findings, when three tomato cultivars were grown in a conventional production system at two field locations that varied in environmental conditions (average air temperature, soil texture, soil $\mathrm{pH}$, soil mineral content) reprogramming of transcription and the metabolome occurs in a genotype-specific manner (D’Espito et al., 2017).

These data on metabolic changes indicate the need to account for agroecosystem effects on "novel" and other engineered crop genotypes for variables like fruit yield, metabolite/nutrient content, and longevity. They also indicate the need for careful selection of crop genotypes that have robust agronomic, and other desirable traits, under different agroecosystems (Grobkinsky et al., 2015); that is, crop genotypes that result in consistent expression of traits across agroecosystems and environments. Metabolic networks across genotypes and agroecosystems highlight differences in the structure of primary metabolic networks and reveal the fluidity of plant metabolic networks; in agreement with the recent discussion on differential networks of plant metabolism (Omranian et al., 2015; D’Espito et al., 2017).

Moreover, hormonal involvement in the regulation of metabolomics appears to be both, specific, and complex. Transgenic tomato fruit genotype deficient in ethylene production is severely limited in the concentration of Krebs cycle metabolites under field conditions relative to when grown in the greenhouse (Sobolev et al., 2014), likely an effect of different levels of UV radiation. Furthermore, greenhouse-grown methyl jasmonate-deficient tomato line bear fruit that are remarkably deficient in several amino acids compared to another transgenic tomato line which over-accumulates polyamines (Mattoo and Abdul-Baki, 2006; Kausch et al., 2012). Conversely, methyl jasmonate-deficient fruit accumulate higher levels of ALA, VAL, ASP, and GLU under field conditions. Under field conditions, even when the energy metabolites-ATP/ADP-are higher in both ethylene- and methyl jasmonate-deficient fruits, fruit from these lines have lower amounts of Krebs cycle intermediates as compared to the same fruit genotypes grown in the greenhouse.

Comparative analysis of the double transgenic fruit (Sobolev et al., 2014) provides additional insights regarding the crosstalk between the high polyamine trait and that of the ethylenedeficiency or methyl jasmonate-deficiency traits (Fatima et al., 2016). The ethylene-deficient trait is dominant over the high polyamine trait. In contrast, the high polyamine (Spd/Spm) trait is dominant in the background of methyl jasmonate deficiency in maintaining higher levels of several amino acids (GLN, ALA, TYR, and GABA) under field conditions. Similarly, the high polyamine trait is dominant for Krebs cycle intermediatescitrate, succinate, and fumarate-and energy-related metabolites (ATP/ADP) under field conditions but not under greenhouse conditions. The conversion of glutamate to succinate catalyzed by glutamate decarboxylase, GABA transaminase, and succinic semialdehyde dehydrogenase have been related to GABA shunt, an alternative pathway for glutamate to enter the Krebs cycle (Michaeli and Fromm, 2015; Takayama and Ezura, 2015), while GABA is emerging as a signaling molecule in stress pathways in plants (Xing et al., 2007; Moschou et al., 2012; Shelp et al., 2017). Catabolism of the polyamine putrescine to GABA has been associated with prevention/delay of senescence (Mattoo and Sobieszczuk-Nowicka, 2019).

Thus, agroecosystem environment can impact the fluidity of metabolite networks while specific interactions between a particular metabolite pathway and growth environment are genotype-specific and influence the metabolite quality of a crop. Future research is needed to define how expression of these traits is modified by agroecosystem environment.

\section{POSSIBILITIES FOR THE FUTURE}

It has become apparent that diets consumed by the world population for the past 50 years are nutrient-limited and have added to erosion of natural biodiversity (Robinson, 2013; Lucas and Horton, 2019). Nutrition studies have established that diet and human health are inter-related for human wellness. Nutritional molecules including vitamins (B, C, E, and $\beta$-carotene), folates, lycopene, flavonoids, isothyocyanates, glucosinolates, polyphenols, glutathione, and minerals contribute to the antioxidative capacity of vegetables, fruits, nuts, and various herbs. Increased consumption of fruits, green vegetables, and foods rich in phytonutrients, protein, and fiber are beneficial to human health. However, the available level of phytonutrients 
in commonly grown crops including vegetables is below the recommended daily allowance (RDA) when consumed as a common serving size and likely a function of how and where these crops are grown. Also, it is noted that the levels of phytonutrients present in horticultural crops are low and significantly influenced by genotype/cultivar, growth condition and developmental stage. In this regard, genetic engineering has become a refined tool to increase the antioxidant and nutrient capacity of economically important crops including fruits and vegetables to levels favorable not only for a highly nutritional diet but also to enable in-depth studies on the relationships between diet, genetics and metabolism.

Maladies such as hypertension, diabetes, osteoporosis and cancer, along with age/lifestyle-related diseases are intertwined with the diet (Mattoo et al., 2010). The possibility that dietary intervention via nutrition-enriched food may significantly decrease incidence of diet-related diseases has catalyzed scientific efforts to understand this relationship. Multiple and synergistic interactions among nutrients influence antiproliferative activity compared with an isolated antioxidant. The true potential of a supplemental antioxidant or crop nutrients in human health benefits is in their accessibility, bioavailability, and biological potency. Deciphering the transcriptome-proteome-metabolome of the new transgenics should provide new knowledge to mitigate societal concerns and open markets for genetically engineered crops, as is apparent from higher sales of Hawaiigrown transgenic papaya in the USA.

Dr. Richard Horton, Editor-in-Chief at The Lancet, wrote: "Poor nutrition is a key driver and risk factor for disease. However, there has been a global failure to address this. It is everyone's and no-one's problem." Research based on personalized medicine has become prominent in recent years to design patient-based diet prescriptions utilizing an individual's health metrics and relevant information harnessed through technologies including genomics, epigenetics, systems biology, and others (Minich and Bland, 2013). The conceptual bases for personalized nutrition include biological evidence specific to an individual's response to foods/nutrients and how these relate to an individual's genotypic/phenotypic characteristics (Ordovas et al., 2018). It is anticipated that personalized nutrition will have tremendous impact on humanity but it is still in infancy. Like human genetics, plant genetics has to provide answers that categorize what keeps plants growing well and what is responsible for their short life span. In this regard, it has been recognized that crop genomes undergo constant changes based on evolution and human intervention. Thus, there is an important need and a huge task to map and sort out available and new crop genomes (Kresovich, 2019).

Other reports view sustainability as a bridge between robust agricultural practices (productivity) and healthy human populations focusing on economical and quality-of-life value to human society (Adams et al., 2016). Breeding strategies for developing food for consumption inadvertently led to modern day cultivars that are richer in carbohydrates (starch and sugar) and deficient in nutrients such as antioxidants, vitamins, minerals, and fiber (Robinson, 2013), as also mentioned above. Adams et al. (2016) opine that intensive agricultural practices lead to foods deficient in nutritional quality and cause increased human risk of chronic diseases and disorders linked to foods high in glycemic index, saturated fat, and lower ratios of omega- 6 to omega- 3 fatty acids. Intake of omega-3 and omega- 6 fatty acids regulates the immune system; omega-6derived hormones stimulate the immune response while omega3-derived hormones are anti-inflammatory (Teng et al., 2014; Adams et al., 2016). A balanced ratio of dietary omega- 6 to omega-3 oils has been recommended to be lower than 10:1, to as low as 2:1 or 1:1 (Simopoulos, 2008, 2011). Notably, the modern Western diet provides a ratio exceeding 10:1, due largely to high ratios found in mass-produced vegetable oils (corn, sunflower, soybean, and cottonseed oil). The plant species used as feed for livestock and food production conditions both affect nutritional quality. Thus, redesigning agriculture for achieving sustainability and utilizing modern genetic engineering tools have an immense advantage in enhancing crop production with an added nutritional dose.

\section{CONCLUSIONS}

Plants provide a diverse collection of essential vitamins, amino acids, fatty acids, and minerals essential in the human diet. Plants also provide a diverse collection of phytonutrients that are not essential but implicated in enhancing human health (Martin and $\mathrm{Li}, 2017)$. These nutrients play a variety of roles in plants and are subject to developmental and environmental cues for their synthesis. Crop production systems, and often uncontrollable environmental conditions in agricultural production fields, impact synthesis and uptake of these nutrients. The number of different nutrients in plant foods, and potential for a differential response to these production system and environmental cues, make it challenging to manipulate crop production systems to produce food that is consistently dense in all desired nutrients. The impact of sustainable cropping systems on crop nutrients is essentially unknown. The use of biologicals (cover crops, beneficial microbes) makes them harder to manage than conventional systems (Mattoo and Teasdale, 2010; Roberts and Kobayashi, 2011). Therefore, it is unlikely if not impossible, to produce foods dense in the desired nutrients solely by management of sustainable production systems.

There is a clear need to increase production of nutritious food while making food production more sustainable (Roberts and Mattoo, 2018). One strategy to do this, as outlined above with the next-generation tomato production system, is to direct crop production system development toward diminishing the substantial impact of the production system on the environment and the development of advanced crop cultivars toward increasing yield and nutritional density of edible portions of the crop. Our work with this sustainable tomato production system demonstrates the ability to develop a crop production system with decreased impact on the environment while at the same time having positive impacts on fruit attributes. This production system substantially influences tomato physiology, shelf-life, longevity, and defense against disease (Mills et al., 2002a,b; Kumar et al., 2004, 2005; Neelam 
et al., 2008; Mattoo and Teasdale, 2010). Therefore, production of sustainable production systems may provide opportunities to further enhance nutritional quality of food beyond that provided by advanced crop germplasm. However, analysis of the impact of crop agroecosystem and crop genotype (in this case, variation in hormone levels) on the tomato metabolite profile indicates that genotype, agroecosystem, and agroecosystem $\times$ crop genotype interactions influence tomato metabolites (Mattoo and AbdulBaki, 2006; Neelam et al., 2008; Fatima et al., 2016). This is consistent with other studies demonstrating the importance of crop genetics, cropping system, and cropping system $\times$ crop genotype interaction on plant metabolite (nutrient) content (e.g., reviewed in Poiroux-Gonord et al., 2010). There is, therefore, a serious need to thoroughly test newly generated crop cultivars in different cropping systems and, likewise, the

\section{REFERENCES}

Abdul-Baki, A. A., and Teasdale, J. R. (1993). A no-tillage tomato production system using hairy vetch and subterranean clover mulches. HortSci. $28,106-108$.

Abdul-Baki, A. A., Teasdale, J. R., and Korcak, R. F. (1997). Nitrogen requirements of fresh-market tomatoes on hairy vetch and block polyethylene mulch. HortSci. 32, 217-221. doi: 10.21273/HORTSCI.32.2.217

Abdul-Baki, A. A., Teasdale, J. R., Korcak, R. F., Chitwood, D. J., and Huettel, R. N. (1996). Fresh-market tomato production in a low-input alternative system using cover-crop mulch. J. Amer. Soc. Hort. Sci. 31, 65-69. doi: 10.21273/HORTSCI.31.1.65

Adams, M. S., Adams, R. B., Wessman, C. A., and Demmig-Adams, B. (2016). Nutritional cues tie living organisms to their environment and its sustainability. Front. Nutr. 3:28. doi: 10.3389/fnut.2016.00028

Albornoz, F. (2016). Crop responses to nitrogen overfertilization: a review. Scientia Hort. 205, 79-83. doi: 10.1016/j.scienta.2016.04.026

Allan, A. C., and Espley, R. V. (2018). MYBs drive novel consumer traits in fruits and vegetables. Trends Plant Sci. 23, 693-705. doi: 10.1016/j.tplants.2018.06.001

Asensi-Fabado, M. A., and Munné-Bosch, S. (2010). Vitamins in plants: occurrence, biosynthesis and antioxidant function. Trends Plant Sci. 1, 582-592. doi: 10.1016/j.tplants.2010.07.003

Backer, R., Rokem, J. S., Ilangumaran, G., Lamont, J., Praslickova, D., Ricci, E., et al. (2018). Plant growth-promoting rhizobacteria: context, mechanisms of action, and roadmap to commercialization of biostimulants for sustainable agriculture. Front. Plant Sci. 10:1473. doi: 10.3389/fpls.2018.01473

Balafoutis, A., Beck, B., Fountas, S., Vangeyte, J., van der Wal, T., Soto, I., et al. (2017). Precision agriculture technologies positively contributing to GHG emissions mitigation, farm productivity and economics. Sustainability 9:1339. doi: $10.3390 /$ su9081339

Beauregard, M., Dupont, C., and Heffard, M. A. (1995). Design, expression and initial characterization of MB1, a de novo protein enriched in essential amino acids. Biotechnology 13, 974-981. doi: 10.1038/nbt0995-974

Beauvoit, B., Belouah, I., Bertin, N., Cakpo, C. B., Colombié, S., Dai, Z., et al. (2018). Putting primary metabolism into perspective to obtain. Ann. Bot. 122, 1-21. doi: 10.1093/aob/mcy057

Bindraban, P. S., Dimpka, C., Nagarajan, L., Roy, A., and Rabbinge, R. (2015). Revisiting fertilisers and fertilization strategies for improved nutrient uptake by plants. Biol. Fertil. Soils 51, 897-911. doi: 10.1007/s00374-015-1039-7

Borlaug, N. E. (2000). Ending world hunger. The promise of biotechnology and the threat of antiscience zealotry. Plant Physiol. 124, 487-490. doi: $10.1104 /$ pp.124.2.487

Bouis, H. E. (2000). Special issue on improving human nutrition through agriculture. Food Nutr. Bull. 21, 351-576. doi: 10.1177/156482650002100441

Bouis, H. E., and Saltzman, A. (2017). Improving nutrition through biofortification: a review of evidence from HarvestPlus, 2003 through 2016. Glob. Food Sec. 1, 49-58. doi: 10.1016/j.gfs.2017.01.009 impact of newly developed cropping systems on crop cultivars regarding nutritional quality of the resulting foodstuff. Robust crop cultivars are needed that consistently express traits across agroecosystems and environments. Likewise, techniques/ideas that result in increased robustness of crop genotype need to be developed and tested (Mattoo, 2014; D’Espito et al., 2017).

\section{AUTHOR CONTRIBUTIONS}

All authors listed have made a substantial, direct and intellectual contribution to the work, and approved it for publication.

\section{FUNDING}

The research of the authors was funded through USDA projects.

Burt, A. J., Grainger, C. M., Smid, M. P., Shelp, B. J., and Lee, E. A. (2011). Allele mining of exotic maize germplasm to enhance macular carotenoids. Crop Sci. 51, 991-1004. doi: 10.2135/cropsci2010.06.0335

Burt, A. J., Grainger, C. M., Young, J. C., Shelp, B. J., and Lee, E. A. (2010). Impact of postharvest handling on carotenoid concentration and composition in highcarotenoid maize (Zea mays L.) kernels. J. Agric. Food. Chem. 58, 8286-8292. doi: $10.1021 /$ jf100161r

Butelli, E., Titta, L., Giorgio, M., Mock, H. P., Matros, A., Peterek, S., et al. (2008). Enrichment of tomato fruit with health-promoting anthocyanins by expression of select transcription factors. Nat. Biotechnol. 26, 1301-1308. doi: 10.1038/nbt.1506

Buyer, J. S., Teasdale, J. R., Roberts, D. P., Zasada, I. A., and Maul, J. (2010). Factors affecting soil microbial community structure in tomato cropping systems. Soil Biol. Biochem. 42, 831-841. doi: 10.1016/j.soilbio.2010.01.020

Cakmak, I. (2009). Enrichment of fertilizers with zinc: An excellent investment for humanity and crop production in India. J. Trace Elem. Med. Biol. 23, 281-289. doi: 10.1016/j.jtemb.2009.05.002

Catín, C. M., Minas, I. S., Goulas, V., Jiménez, Manganaris, G. A., Michailides, T. J., and Crisosto, C. H. (2012). Sulfur dioxide fumigation alone or in combination with $\mathrm{CO}_{2}$ - enriched atmosphere extends the market life of highbush blueberry fruit. Postharvest Biol. Technol. 67, 84-91. doi: 10.1016/j.postharvbio.2011.12.006

Cheynier, V., Comte, G., Davies, K. M., Lattanzio, V., and Martens, S. (2013). Plant phenolics: recent advances on their biosynthesis, genetics, and ecophysiology. Plant Physiol. Biochem. 72, 1-20. doi: 10.1016/j.plaphy.2013.05.009

Chong, J., Poutaraud, A., and Hugueney, P. (2009). Metabolism and roles of stilbenes in plants. Plant Sci. 177, 143-155. doi: 10.1016/j.plantsci.2009.05.012

Cosgrove, D. J., Irving, G. C. J., and Bromfield, S. M. (1970). Inositol phosphate phosphatases of microbial origin. The isolation of soil bacteria having inositol phosphate phosphatase activity. Aust. J. Biol. Sci. 23, 339-343. doi: 10.1071/BI9700339

Costa, J. M., Ortuno, M. F., and Chaves, M. M. (2007). Deficit irrigation as a strategy to save water: physiology and potential application to horticulture. $J$. Integr. Plant Biol. 49, 1421-1434. doi: 10.1111/j.1672-9072.2007.00556.x

Crespo, P., Bordonaba, J. G., Terry, L. A., and Carlen, C. (2010). Characterisation of major taste and health-related compounds of four strawberry genotypes grown at different Swiss production sites. Food Chem. 122, 16-24. doi: 10.1016/j.foodchem.2010.02.010

Czarnocka, W., and Karpinski, S. (2018). Friend or foe? reactive oxygen species production, scavenging and signaling in plant response to environmental stress. Free Rad. Biol. Med. 122, 4-20. doi: 10.1016/j.freeradbiomed.2018.01.011

Das, K., and Roychoudhury, A. (2014). Reactive oxygen species (ROS) and response of antioxidants as ROS-scavengers during environmental stress in plants. Front. Environ. Sci. 2:53. doi: 10.3389/fenvs.2014.00053

Davies, K. M., Albert, N. W., and Schwinn, K. E. (2012). From landing lights to mimicry: the molecular regulation of flower colouration and mechanisms for pigmentation patterning. Funct. Plant Biol. 39, 619-638. doi: 10.1071/FP12195 
DellaPenna, D., and Pogson, B. J. (2006). Vitamin synthesis in plants: tocopherols and carotenoids. Annu. Rev. Plant Biol. 57, 711-738. doi: 10.1146/annurev.arplant.56.032604.144301

Deluc, L. G., Quilici, D. R., Decendit, A., Grimplet, J., Wheatley, M. D., Schlauch, K. A., et al. (2009). Water deficit alters differentially metabolic pathways affecting important flavor and quality traits in grape berries of Cabernet Sauvignon and Chardonnay. BMC Genomics 10:212. doi: 10.1186/1471-2164-10-212

D'Espito, D., Ferriello, F., Dal Molin, A., Diretto, G., Sacco, A., Minio, A., et al. (2017). Unraveling the complexity of transcriptomic, metabolomic and quality environmental response of tomato fruit. BMC Plant Biol. 17:66. doi: 10.1186/s12870-017-1008-4

Díaz-Gómez, J., Twyman, R. M., Zhu, C., Farré, G., Serrano, J. C. E., Portero-Otin, M., et al. (2017). Biofortification of crops with nutrients: factors affecting utilization and storage. Curr. Opin. Biotechnol. 44, 115-123. doi: 10.1016/j.copbio.2016.12.002

Dimpka, C. O., and Bindraban, P. S. (2016). Fortification of micronutrients for efficient agronomic production: a review. Agron. Sust. Dev. 36:7. doi: 10.1007/s13593-015-0346-6

Dixon, R. A., Achnie, L., Kota, P., Liu, C.-J., Reddy, M. S. S., and Wang, L. (2002). The phenylpropanoid pathway and plant defense - a genomics perspective. Mol. Plant Pathol. 3, 371-390. doi: 10.1046/j.1364-3703.2002. 00131.x

Dubos, C., Stracke, R., Grotewold, E., Weisshaar, B., Martin, C., and Lepiniec, L. (2010). MYB transcription factors in Arabidopsis. Trends Plant Sci. 15, 573-581. doi: 10.1016/j.tplants.2010.06.005

Eggeling, L., Oberle, S., and Sahm, H. (1998). Improved L-lysine yield with Cornebacterium glutamicum: use of $\operatorname{dapA}$ resulting in increased flux combined with growth limitation. Appl. Microbiol. Biotechnol. 49, 24-30. doi: $10.1007 / \mathrm{s} 002530051132$

Esteban, R., Moran, J. F., Becerril, J. M., and Garcia-Plazaola, J. I. (2015). Versatility of carotenoids: anintegrated view on diversity, evolution, functional roles and environmental interactions. Env. Exper. Bot. 119, 63-75. doi: 10.1016/j.envexpbot.2015.04.009

Falco, S. C., Guida, T., Locke, M., Mauvais, J., Sanders, C., Ward, R. T., et al. (1995). Transgeneic canola and soybean seeds with increased lysine. BioTechnology 13, 577-582. doi: 10.1038/nbt0695-577

Fanciullino, A. L., Bidel, L. P. R., and Urban, L. (2013). Carotenoid responses to environmental stimuli: integrating redox and carbon control into a fruit model. Plant Cell Environ. 37, 273-289. doi: 10.1111/pce.12153

Fatima, T., Handa, A. K., and Mattoo, A. K. (2013). "Functional foods: genetics, metabolome, and engineering phytonutrient levels," in Natural Products, eds K. G. Ramawat, and J. M. Merillon (Heidelberg: Springer-Verlag), 1715-1749. doi: 10.1007/978-3-642-221 44-6_50

Fatima, T., Sobolev, A. P., Teasdale, J. R., Kramer, M., Bunce, J., Handa, A. K., et al. (2016). Fruit metabolite networks in engineered and non-engineered tomato genotypes reveal fluidity in a hormone and agroecosystem specific manner. Metabolomics 12:103. doi: 10.1007/s11306-016-1037-2

Fatima, T., Teasdale, J. R., Bunce, J., and Mattoo, A. K. (2012). Tomato response to legume cover crop and nitrogen: differing enhancement patterns of fruit yield, photosynthesis and gene expression. Funct. Plant Biol. 39, 246-254. doi: 10.1071/FP11240

Finkel, O. M., Castrillo, G., Herrera Paredes, S., González, S., and Dangl, J. L. (2017). Understanding and exploiting plant beneficial microbes. Curr. Opin. Plant Biol. 38, 155-163. doi: 10.1016/j.pbi.2017.04.018

Foley, J. A., Ramankutty, N., Brauman, K. A., Cassidy, E. S., Gerber, J. S., Johnston, M., et al. (2011). Solutions for a cultivated planet. Nature 478, 337-342. doi: $10.1038 /$ nature 10452

Foyer, C. H. (2018). Reactive oxygen species, oxidative signaling and the regulation of photosynthesis. Environ. Exper. Bot. 154, 134-142. doi: 10.1016/j.envexpbot.2018.05.003

Frank, H. A., and Cogdell, R. J. (1996). Carotenoids in photosynthesis. Photochem. Photobiol. 63, 257-264. doi: 10.1111/j.1751-1097.1996.tb03022.x

Fraser, P. D., Truesdale, M. R., Bird, C. R., Schuch, W., and Bramley, P. M. (1994). Carotenoid biosynthesis during tomato fruit development (evidence for tissue-specific gene expression). Plant Physiol. 105, 405-413. doi: 10.1104/pp.105.1.405
Fukushima, A., Kusano, M., Redestig, H., Arita, M., and Saito, K. (2011). Metabolomic correlation-network modules in Arabidopsis based on a graphclustering approach. BMC Syst. Biol. 5:1. doi: 10.1186/1752-0509-5-1

Gan, Y. T., Miller, P. R., McConkey, B. G., Zentner, R. P., Stevenson, F. C., and McDonald, C. L. (2003). Influence of diverse cropping sequences on durum wheat yield and protein in the semiarid northern Great Plains. Agron. J. 95, 245-252. doi: 10.2134/agronj2003.0245

Gautier, H., Diakou-Verdin, V., Bénard, C., Reich, M., Buret, M., Bourgaud, F., et al. (2008). How does tomato quality (sugar, acid, and nutritional quality) vary with ripening stage, temperature, and irradiance? J. Agric. Food Chem. 56, 1241-1250. doi: 10.1021/jf072196t

Gebbers, R., and Adamchuk, V. I. (2010). Precision agriculture and food security. Science 327, 828-831. doi: 10.1126/science.1183899

Gerdes, S., Lerma-Ortiz, C., Frelin, O., Seaver, S. M. D., Henry, D. S., Crécy-Lagard, V., et al. (2012). Plant vitamin B pathways and their compartmentation: a guide for the perplexed. J. Exp. Bot. 63, 5379-5395. doi: 10.1093/jxb/ers208

Goméz-Galera, S., Rojas, E., Sudhakar, D., Zhu, C., Pelacho, A. M., Capell, T., et al. (2010). Critical evaluation of strategies for mineral fortification of staple food crops. Transgenic Res. 19, 165-180. doi: 10.1007/s11248-009-9311-y

Gracía Plazaola, J., Esteban, R., Fernández-Mariín, B., Kranner, I., and Porcar-Castell, A. (2012). Thermal energy dissipation and xanthophyll cycles beyond the Arabidopsis model. Photosynth. Res. 113, 89-103. doi: $10.1007 / \mathrm{s} 11120-012-9760-7$

Graham, R. D., Welch, R. M., and Bouis, H. E. (2001). Addressing micronutrient malnutrition through enhancing the nutritional quality of staple foods: principles, perspectives and knowledge gaps. Adv. Agron. 70, 77-142. doi: 10.1016/S0065-2113(01)70004-1

Grobkinsky, D. K., Svensgaard, J., Christensen, S., and Roitsch, T. (2015). Plant phenomics and the need for physiological pheno-typing across scales to narrow the genotype-to-phenotype knowledge gap. J. Exp. Bot. 66, 5429-5440. doi: 10.1093/jxb/erv345

Grusak, M. A. (2002). Enhancing mineral content in plant food products. J. Amer. Coll. Nutr. 21, 178S-183S. doi: 10.1080/07315724.2002.10719263

Grusak, M. A., and DellaPenna, D. (1999). Improving the nutrient composition of plants to enhance human nutrition and health. Annu. Rev. Plant Physiol. Plant Mol. Biol. 50, 133-161. doi: 10.1146/annurev.arplant.50.1.133

Hanson, A. D., Beaudoin, G. A., McCartry, D. R., and Gregory, I. I. I. J. F. (2016). Does abiotic stress cause functional B vitamin deficiency in plants? Plant Physiol. 172, 2082-2097. doi: 10.1104/pp.16. 01371

Hell, R., and Hillebrand, H. (2001). Plant concepts for mineral acquisition and allocation. Curr. Opin. Biotechnol. 12, 161-168. doi: 10.1016/S0958-1669(00)00193-2

Hichri, I., Barrieu, F., Bogs, J., Kappel, C., Delrot, S., and Lauvergeat, V. (2011). Recent advances in the transcriptional regulation of the flavonoid biosynthetic pathway. J. Exp. Bot. 62, 2465-2483. doi: 10.1093/jxb/erq442

Hirschi, K. D. (2009). Nutrient biofortification of food crops. Annu. Rev. Nutri. 29, 401-429. doi: 10.1146/annurev-nutr-080508-141143

Hugueney, P., Bouvier, F., Badillo, A., Quennement, J., D'Harlingue, A., and Camara, B. (1996). Developmental and stress regulation of gene expression for plastid and cytosolic isoprenoid pathways in pepper fruits. Plant Physiol. 111, 619-626. doi: 10.1104/pp.111.2.619

Joy, E. J. M., Stein, A. J., Young, S. D., Ander, E. L., Watts, M. J., and Broadley, M. R. (2015). Zinc-enriched fertilizers as a potential public health intervention in Africa. Plant Soil 389, 1-24. doi: 10.1007/s11104-015-2430-8

Kato, M., Ikoma, Y., Matsumoto, H., Sugiura, M., Hyodo, H., and Yano, M. (2004). Accumulation of carotenoids and expression of carotenoid biosynthetic genes during maturation in citrus fruit. Plant Physiol. 134, 824-837. doi: 10.1104/pp.103.031104

Kausch, K. D., Sobolev, A. P., Goyal, R. K., Fatima, T., Laila-Beevi, R., Saftner, R. A., et al. (2012). Methyl jasmonate deficiency alters cellular metabolome, including the aminome of tomato (Solanum lycopersicum L.) fruit. Amino Acids 42, 843-856. doi: 10.1007/s00726-011-1000-5

Kelly, T. C., Lu, Y.-C., Abdul-Baki, A. A., and Teasdale, J. R. (1995). Economics of a hairy vetch mulch system for producing fresh-market tomatoes in the mid-Atlantic region. J. Amer. Soc. Hort. Sci. 120, 854-860. doi: 10.21273/JASHS.120.5.854 
Khoshgoftarmanesh, A. H., Schullin, R., Chaney, R. L., Daneshbakhsh, B., and Afyuni, M. (2010). Micronutrient-efficient genotypes for crop yield and nutritional quality in sustainable agriculture. A review. Agron. Sustain. Dev. 30, 83-107. doi: 10.1051/agro/2009017

Kresovich, S. (2019). Can we feed the world in a healthy sustainable way? ClemsonWorld Res. 35.

Kumar, V., Abdul-Baki, A., Anderson, J. D., and Mattoo, A. K. (2005). Cover crop residues enhance growth, improve yield, and delay leaf senescence in greenhouse-grown tomatoes. HortSci. 40, 1307-1311. doi: 10.21273/HORTSCI.40.5.1307

Kumar, V., Mills, D. J., Anderson, J. D., and Mattoo, A. K. (2004). An alternative agriculture system is defined by a distinct expression profile of select gene transcripts and proteins. Proc. Natl. Acad. Sci. USA. 101, 10535-10540. doi: 10.1073/pnas.0403496101

Kyriacou, M. C., and Rouphael, Y. (2018). Towards a new definition of quality for fresh fruits and vegetables. Scientia Hort. 234, 463-469. doi: 10.1016/j.scienta.2017.09.046

Le, D. T., Chu, H. D., and Le, N. Q. (2016). Improving nutritional quality of plant proteins through genetic engineering. Curr. Genomics 17, 220-220. doi: 10.2174/1389202917666160202215934

Lei, W. Q., Khanizadeh, S., and Vigneault, C. (2007). Preharvest ways of enhancing the phytochemical content of fruits and vegetables. Stewart Postharv. Rev. 3:3. doi: 10.2212 /spr.2007.3.3

Lester, G. E., and Saftner, R. A. (2011). Organically versus conventionally grown produce: common production inputs, nutritional quality, and nitrogen delivery between the two systems. Agric. Food Chem. 59, 10401-10406. doi: $10.1021 /$ jf $202385 \mathrm{x}$

Liu, H. L. (2013). Health-promoting components of fruits and vegetables in the diet. Adv. Nutr. 4, 384S-3925S. doi: 10.3945/an.112.003517

Liu, J., Osbourn, A., and Ma, P. (2015a). MYB transcription factors as regulators of phenylpropanoid metabolism in plants. Mol. Plant. 8, 689-708. doi: 10.1016/j.molp.2015.03.012

Liu, L., Shao, Z., Zhang, M., and Wang, Q. (2015b). Regulation of carotenoid metabolism in tomato. Mol. Plant. 8, 28-39. doi: 10.1016/j.molp.2014.11.006

Loneragan, J. F. (1997). Plant nutrition in the $20^{\text {th }}$ and perspectives for the $21^{\text {st }}$ century. Plant Soil 196, 163-174. doi: 10.1023/A:10042086 21263

Low, J. W., Mwanga, R., Andrade, M., Carey, E., and Ball, A. (2017). Tackling vitamin A deficiency with biofortified sweet potato in sub-Saharan Africa. Glob. Food Secur. 14, 23-30. doi: 10.1016/j.gfs.2017.01.004

Lu, C., Hawkesford, M. J., Barraclough, P. B., Poulton, P. R., Wilson, I. D., Barker, G. L., et al. (2005). Markedly different gene expression in wheat grown with organic or inorganic fertilizer. Proc. Biol. Sci. 272, 1901-1908. doi: $10.1098 /$ rspb.2005.3161

Lucas, T., and Horton, R. (2019). The $21^{\text {st }}$-century great food transformation. Lancet 393, 386-387. doi: 10.1016/S0140-6736(18)33179-9

Lushchak, V. I., and Semchuk, N. M. (2012). Tocopherol biosynthesis: chemistry, regulation and effects of environmental factors. Acta Physiol. Plant 34, 1607-1628. doi: 10.1007/s11738-012-0988-9

Malhi, S. S., Grant, G. A., Johnston, A. M., and Gill, K. S. (2001). Nitrogen fertilization management for no-till cereal production in Canadian great plan: a review. Soil Till. Res. 60, 101-122. doi: 10.1016/S0167-1987(01)00176-3

Malhi, S. S., and Nyborg, M. (1990). Effect of tillage and straw on yield and N uptake of barley grown under different N fertility regimes. Soil Till. Res. 17, 115-124. doi: 10.1016/0167-1987(90)90010-B

Manganaris, G. A., Goulas, V., Vicente, A. R., and Terry, L. (2014). Berry antioxidants: small fruits providing large benefits. J. Sci. Food Agric. 94, 825-833. doi: 10.1002/jsfa.6432

Martin, C. (2013). The interface between plant metabolic engineering and human health. Curr. Opin. Biotechnol. 24, 344-353. doi: 10.1016/j.copbio.2012.11.005

Martin, C., Butelli, E., Petroni, K., and Tonelli, C. (2011). How can research on plants contribute to promoting human health. Plant Cell. 23, 1685-1699. doi: $10.1105 /$ tpc. 111.083279

Martin, C., and Li, J. (2017). Medicine is not health care, food is health care: plant metabolic engineering, diet and human health. N. Phytol. 216, 699-719. doi: $10.1111 /$ nph.14730

Martínez-Ballesta, M. C., Dominguez-Perles, R., Moreno, D. A., Muries, B., Alcaraz-López, C., Bastías, E., et al. (2010). Minerals in plant food: effect of agricultural practices and role in human health. A review. Agron. Sutsain. Dev. 30, 295-309. doi: 10.1051/agro/2009022

Matson, P. A., Parton, W. J., Power, A. G., and Smith, M. J. (1997). Agricultural intensification and ecosystem properties. Science 277, 504-509. doi: $10.1126 /$ science.277.5325.504

Mattoo, A. K. (2014). Translational research in agricultural biotechnology enhancing crop resistivity against environmental stress alongside nutritional quality. Front. Chem. 2:30. doi: 10.3389/fchem.2014.00030

Mattoo, A. K., and Abdul-Baki, A. (2006). "Crop genetic responses to management: evidence of root-to-shoot communication," in Biological Approaches to Sustainable Soil Systems, eds E. Fernandes, A. S. Ball, H Herren, N. Uphoff. (Boca Raton, FL: Taylor and Francis), 221-230. doi: 10.1201/9781420017113.ch15

Mattoo, A. K., and Handa, A. K. (2008). Higher polyamines restore and invigorate metabolic meory in ripening fruit. Plant Sci. 174, 386-393. doi: 10.1016/j.plantsci.2008.01.011

Mattoo, A. K., Shukla, V., Fatima, T., Handa, A. K., and Yachha, S. K. (2010). "Genetic engineering to enhance crop-based phytonutrients (nutraceuticals) to alleviate diet-related diseases," in Bio-Farms for Nutraceuticals: Functional Food and Safety Control by Biosensors, eds M. T. Giardi, G. Rea, B. Berra (Landes Bioscience and Springer Science + Business Media), 122-143. doi: 10.1007/978-1-4419-7347-4_10

Mattoo, A. K., and Sobieszczuk-Nowicka, E. (2019). "Polyamine as signaling molecules and leaf senescence," in Senescence Signaling and Control in Plants, eds M. Sarwat, N. Tuteja (Cambridge, MA: Academic Press), 125-138. doi: 10.1016/B978-0-12-813187-9.00008-1

Mattoo, A. K., and Teasdale, J. R. (2010). Ecological and genetic systems underlying sustainable horticulture. Hort. Rev. 37, 331-362. doi: 10.1002/9780470543672.ch6

Mehta, R. A., Cassol, T., Li, N., Ali, N., Handa, A. K., and Mattoo, A. K. (2002). Engineered polyamine accumulation in tomato enhances phytonutrient content, juice quality, and vine life. Nat. Biotechnol. 20, 613-618. doi: $10.1038 /$ nbt0602-613

Memelink, J., Hoge, J. H. C., and Schilperoort, R. A. (1987). Cytokinin stress changes the developmental regulation of several defense-related genes in tobacco. EMBO J. 6, 3579-3583. doi: 10.1002/j.1460-2075.1987.tb02688.x

Mène-Saffrané, L., and DellaPenna, D. (2010). Biosynthesis, regulation and functions of tocochromanols in plants. Plant Physiol. Biochem. 48, 301-309. doi: 10.1016/j.plaphy.2009.11.004

Michaeli, S., and Fromm, H. (2015). Closing the loop on the GABA shunt in plants: Are GABA metabolism and signaling entwined? Front. Plant Sci. 6:419. doi: 10.3389/fpls.2015.00419

Mills, D. J., Coffman, B., Teasdale, J. R., Everts, K. L., Abdul-Baki, A. A., Lydon, J., et al. (2002a). Foliar disase in fresh-market tomato grown in differing bed strategies and fungicide spray programs. Plant Dis. 86, 955-959. doi: 10.1094/PDIS.2002.86.9.955

Mills, D. J., Coffman, B., Teasdale, J. R., Everts, K. L., and Anderson, J. D. (2002b). Factors associated with foliar disease of staked fresh market tomatoes grown under differing bed strategies. Plant Dis. 86, 356-361. doi: 10.1094/PDIS.2002.86.4.356

Minich, D. M., and Bland, J. S. (2013). Personalized lifestyle medicine: relevance to nutrition and lifestyle recommendations. Sci. World J. 2013:129841. doi: 10.1155/2013/129841

Moschou, P. N., Wu, J., Cona, A., Tavladoraki, P., Angelini, R., and RoubelakisAngelakis, K. A. (2012). The polyamines and their catabolic products are significant players in the turnover of nitrogenous molecules in plants. J. Exp. Bot. 63, 695-709. doi: 10.1093/jxb/ers202

Mozzo, M., Dall'Osto, L., Hienerwadel, R., Bassi, R., and Croce, R. (2008). Photoprotection in the antenna complexes of Photosystem II: role of individual xanthophylls in chlorophyll triplet quenching. J. Biol. Chem. 283, 6184-6192. doi: 10.1074/jbc.M708961200

Muñoz, C., Sánchez-Sevilla, J. F., Botella, M. A., Hoffmann, T., Schwab, W., and Valpuesta, V. (2011). Polyphenol composition in the ripe fruits of Fragaria species and transcriptional analyses of key genes in the pathway. J. Agric. Food Chem. 59, 12598-12604. doi: 10.1021/jf203965j

Neelam, A., Cassol, T., Mehta, R. A., Abdul-Baki, A. A., Sobolev, A., Goyal, R. K., et al. (2008). A field-grown transgenic tomato line expressing higher levels of polyamines reveals legume cover crop mulch-specific perturbations in fruit 
phenotype at the levels of metabolite profiles, gene expression and agronomic characteristics. J. Exp. Bot. 59, 2337-2346. doi: 10.1093/jxb/ern100

Newell-McGloughlin, M. (2008). Nutritionally improved agricultural crops. Plant Physiol. 147, 939-953. doi: 10.1104/pp.108.121947

Newton, A. C., Akar, T., Baresel, J. P., Bebeli, P. J., Bettencourt, E., Bladenopoulos, K. V., et al. (2010). Cereal landraces for sustainable agriculture. A review. Agron. Sustain. Dev. 30, 237-269. doi: 10.1051/agro/2009032

Noctor, G., Reichheld, J.-P., and Foyer, C. H. (2018). ROS-related redox regulation and signaling in plants. Seminars Cell Devel. Biol. 89, 3-12. doi: 10.1016/j.semcdb.2017.07.013

Noh, Y. S., and Amasino, R. M. (1999). Identification of a promoter region responsible for the senescence-specific expression of SAG12. Plant Mol. Biol. 41, 181-194. doi: 10.1023/A:1006342412688

Oliver, M. A., and Gregory, P. J. (2015). Soil, food security and human health: a review. Eur. J. Soil Sci. 66, 257-276. doi: 10.1111/ejss.12216

Omranian, N., Kleessen, S., Tohge, T., Klie, S., Basler, G., Mueller-Roeber, B., et al. (2015). Differential metabolic and co-expression networks of plant metabolism. Trends Plant Sci. 20, 266-268. doi: 10.1016/j.tplants.2015.02.002

O'Quinn, P. R., Nelssen, J. L., Goodband, R. D., Knabe, D. A., Woodworth, J. C., Tokach, M. D., et al. (2000). Nutritional value of a genetically improved high-lysine, high-oil corn for young pigs. J. Anim. Sci. 78, 2144-2149. doi: $10.2527 / 2000.7882144 \mathrm{x}$

Ordovas, J. M., Ferguson, L. R., Tal, E. S., and Mathers, J. C. (2018). Personalised nutrition and health. BMJ 13:361. doi: 10.1136/bmj.k2173

Palmgren, M. G., Clemens, S., Williams, L. E., Krämer, U., Borg, S., Schjorring, and Sanders, D. (2008). Zinc biofortification of cereals: problems and solutions. Trends Plant Sci. 13, 464-473. doi: 10.1016/j.tplants.2008. 06.005

Papon, N., Clastre, M., Andreu, F., Gantet, P., Rideau, M., and Créche, J. (2002). Expression analysis in plant and cell suspensions of CrCKR1, a cDNA encoding histidine kinase receptor homologue in Catharanthus roseus (L.) G. Don. J. Exp. Bot. 53, 1989-1990. doi: 10.1093/jxb/erf048

Pieterse, C. M. J., Zamioudis, C., Berendsen, R. L., Weller, D. M., Van Wees, S. C. M., and Bakker, A. H. M. (2014). Induced systemic resistance by beneficial microbes. Annu. Rev. Phytopathol. 52, 347-375. doi: 10.1146/annurev-phyto-082712-1 02340

Poiroux-Gonord, F., Bidel, L. P. R., Fanciullino, A.-L., Gautier, H., Lauri-Lopez, F., and Urban, L. (2010). Health benefits of vitamins and secondary metabolites of fruits and vegetables and prospects to increase their concentrations by agronomic approaches. J. Agric. Food Chem. 58, 12065-12082. doi: $10.1021 /$ jf1037745

Pradel, E., and Boquet, P. L. (1988). Acid phosphatases of Escherichia coli: molecular cloning and analysis of agp, the structural gene for a periplasmic acid glucose phosphatase. J. Bacteriol. 170, 4916-4923. doi: $10.1128 /$ jb.170.10.4916-4923.1988

Rawat, N., Neelam, K., Tiwari, V. K., and Dhaliwal, H. (2013). Biofortification of cereals to overcome hidden hunger. Plant Breed. 132, 437-445. doi: $10.1111 /$ pbr.12040

Reganold, J. P., and Wachter,. J. M. (2016). Organic agriculture in the twenty-first century. Nat. Plants 2:15221. doi: 10.1038/nplants.2015.221

Rengel, Z., Batten, G. D., and Crowley, D. E. (1999). Agronomic approaches for improving the micronutrient density in edible portions of field crops. Field Crops Res. 60, 27-40. doi: 10.1016/S0378-4290(98)00131-2

Rice, P. J., McConnell, L. L., Heighton, L. P., Sadeghi, A. M., Isensee, A. R., Teasdale, J. R., et al. (2001). Runoff loss of pesticides and soil: a comparison between vegetative mulch and plastic mulch in vegetable production systems. J. Environ. Qual. 30, 1808-1821. doi: 10.2134/jeq2001.3051808x

Rice, P. J., McConnell, L. L., Heighton, L. P., Sadeghi, A. M., Isensee, A. R., Teasdale, J. R., et al. (2002). Comparison of copper levels in runoff from freshmarket vegetable production using polyethylene mulch or a vegetative mulch. Environ. Tox. Chem. 21, 24-30. doi: 10.1002/etc.5620210104

Roberts, D. P., and Kobayashi, D. K. (2011). "Impact of spatial heterogeneity within spermosphere and rhizosphere environments on performance of bacterial biological control agents," in Bacteria in Agrobiology: Crop Ecosystems, ed D. K. Maheshwari (Berlin, Heidelberg: Springer-Verlag), 111-130. doi: 10.1007/978-3-642-18357-7_5
Roberts, D. P., and Mattoo, A. K. (2018). Sustainable agriculture - enhancing environmental benefits, food nutritional quality and building crop resilience to abiotic and biotic stresses. Agriculture 8:8. doi: 10.3390/agriculture8010008

Robinson, J. (2013). Eating on the Wild Side: The Missing Link to Optimum Health. New York, NY: Little, Brown and Company.

Rodriguez, H., and Fraga, R. (1999). Phosphate solubilizing bacteria and their role in plant growth promotion. Biotechnol. Adv. 17, 319-339. doi: 10.1016/S0734-9750(99)00014-2

Roje, S. (2007). Vitamin B biosynthesis in plants. Phytochemistry 68, 1904-1921. doi: 10.1016/j.phytochem.2007.03.038

Rolland, N., Curien, G., Finazzi, G., Kuntz, M., Marechal, E., Matringe, M., et al. (2012). The biosynthetic capacities of the plastids and integration between cytoplasmic and chloroplast processes. Annu. Rev. Genet. 46, 233-264. doi: 10.1146/annurev-genet-110410-132544

Rosegrant, M. W., and Cline, S. A. (2003). Global food security: Challenges and policies. Science 302, 1917-1919. doi: 10.1126/science.1092958

Rouphael, Y., and Kyriacou, M. C. (2018). Enhancing quality of fresh vegetables through salinity eustress and biofortification applications facilitated by soilless cultivation. Front. Plant Sci. 9:1254. doi: 10.3389/fpls.2018. 01254

Rouphael, Y., Kyriacou, M. C., Petropoulos, S. A., De Pascale, S., and Colla, G. (2018). Improving vegetable quality in controlled environments. Sci. Hort. 234, 275-289. doi: 10.1016/j.scienta.2018.02.033

Roy, S. (2016). Function of MYB domain transcription factors in abiotic stress and epigenetic control of stress response in plant genome. Plant Signal Behav. 11:1. doi: 10.1080/15592324.2015.1117723

Sashidhar, B., and Podile, A. R. (2010). Mineral phosphate solubilization by rhizosphere bacteria and scope for manipulation of the direct oxidation pathway involving glucose dehydrogenase. J. Appl. Microbiol. 109, 1-12. doi: 10.1111/j.1365-2672.2009.04654.x

Shelp, B. J., Bown, A. W., and Zarel, A. (2017). 4-Aminobutyrate (GABA): a metabolite and signal with practical significance. Botany 95, 1015-1032. doi: 10.1139/cjb-2017-0135

Shen, J., Yuan, L., Zhang, J., Li, H., Bai, Z., Chen, X., et al. (2011). Phosphorus dynamics: from soil to plant. Plant Physiol. 156, 997-1005. doi: 10.1104/pp.111.175232

Shukla, V., and Mattoo, A. K. (2009). Potential for engineering horticultural crops with high antioxidant capacity. CAB Rev. Persp. Agricul. Vet. Sci. Nutr. Nat. Res. 4, 1-22. doi: 10.1079/PAVSNNR20094066

Shuman, L. M. (1998). Micronutrient fertilizers. J. Crop Prod. 1, 165-195. doi: 10.1300/J144v01n02_07

Simopoulos, A. P. (2008). The importance of the omega-6/omega-3 fatty acid ratio in cardiovascular disease and other chronic diseases. Exp. Biol. Med. 233, 674-688. doi: 10.3181/0711-MR-311

Simopoulos, A. P. (2011). Evolutionary aspects of diet: the omega-6/omega-3 ratio and the brain. Mol. Neurobiol. 44, 203-215. doi: 10.1007/s12035-010-8162-0

Sindu, A., Zheng, Z., and Murai, N. (1997). The pea seed storage protein legumin was synthesized, processed and accumulated stably in transgenic rice endosperm. Plant Sci. 130, 189-196. doi: 10.1016/S0168-9452(97)00219-7

Smirnoff, N. (2000). Ascorbic acid: metabolism and functions of a multi-facetted molecule. Curr. Opin. Plant Biol. 3, 229-235. doi: 10.1016/S1369-5266(00)00069-8

Smith, A. G., Croft, M. T., Moulin, M., and Webb, M. E. (2007). Plants need their vitamins too. Curr. Opin. Plant Biol. 10, 266-275. doi: 10.1016/j.pbi.2007.04.009

Sobolev, A. P., Neelam, A., Fatima, T., Shukla, V., Handa, A. K., and Mattoo, A. K. (2014). Genetic introgression of ethylene-suppressed transgenic tomatoes with higher-polyamines trait overcomes many unintended effects due to reduced ethylene on the primary metabolome. Front. Plant Sci. 5:632. doi: 10.3389/fpls.2014.00632

Stoger, E., Parker, M., Christou, P., and Casey, R. (2001). Pea legumin overexpressed in wheat endosperm assembles into an ordered paracrystalline matrix. Plant Physiol. 125, 1732-1742. doi: 10.1104/pp.125.4.1732

Stracke, R., Werber, M., and Weisshaar, B. (2001). The R2R3-MYB gene family in Arabidopsis thaliana. Curr. Opin. Plant Biol. 4, 447-456. doi: 10.1016/S1369-5266(00)00199-0

Strobbe, S., and Van Der Straeten, D. (2017). Folate biofortification in food crops. Curr. Opin. Biotechnol. 44, 202-211. doi: 10.1016/j.copbio.2016.12.003 
Takayama, M., and Ezura, H. (2015). How and why does tomato accumulate a large amount of GABA in the fruit? Front. Plant Sci. 6:612. doi: $10.3389 /$ fpls.2015.00612

Teasdale, J. R., and Abdul-Baki, A. A. (1997). Growth analysis of tomatoes in black polyethylene and hairy vetch production systems. Hort Sci. 32, 659-663.

Teasdale, J. R., Abdul-Baki, A. A., Mills, D. J., and Thorpe, K. W. (2004). Enhanced pest management with cover crop mulches. Acta Hort. 638, 135-140. doi: 10.17660/ActaHortic.2004.638.16

Teng, K.-T., Chang, C.-Y., Chang, L. F., and Nesaretnam, K. (2014). Modulation of obesity-induced inflammation by dietary fats: mechanisms and clinical evidence. Nutr. J. 13, 12-27. doi: 10.1186/1475-2891-13-12

Thomas, J. C., Smigocki, A. C., and Bohnert, H. J. (1995). Light-induced expression of ipt from Agrobacterium tumefaciens results in cytokinin accumulation and osmotic stress symptoms in transgenic tobacco. Plant Mol. Biol. 27, 225-235. doi: $10.1007 /$ BF00020179

Tilman, D., Fargione, J., Wolff, B., D’Antonio, C., Dobson, A., Howarth, R., et al. (2001). Forecasting agriculturally driven global environmental change. Science 292, 281-284. doi: 10.1126/science. 1057544

Tripathy, B. C., and Oelmüller, R. (2012). Reactive oxygen species generation and signaling in plants. Plant Signal. Behav. 7, 1621-1633. doi: 10.4161/psb. 22455

Triplett, G. B. Jr., and Dick, W. A. (2008). No-tillage crop production: a revolution in agriculture! Agron. J. 100, S153-S165. doi: 10.2134/agronj2007. $0005 c$

Van Wees, S. C. M., Van der Ent, S., and Pieterse, C. M. J. (2008). Plant immune responses triggered by beneficial microbes. Curr. Opin. Plant Biol. 11, 443-448. doi: 10.1016/j.pbi.2008.05.005

Vasconcelos, M. W., Gruissem, W., and Bhullar, N. K. (2017). Iron biofortification in the 21st century: setting realistic targets, overcoming obstacles, and new strategies for healthy nutrition. Curr. Opin. Biotechnol. 44, 8-15. doi: 10.1016/j.copbio.2016.10.001

Vogt, T. (2010). Phenylpropanoid biosynthesis. Molec. Plant. 3, 2-20. doi: $10.1093 / \mathrm{mp} / \mathrm{ssp} 106$

Wang, T. L., Domoney, C., Hedley, C. L., Casey, R., and Grusak, M. A. (2003). Can we improve the nutritional quality of legume seeds? Plant Physiol. 131, 886-891. doi: $10.1104 /$ pp.102.017665
Wang, Z. H., Li, S. X., and Malhi, S. (2008). Effects of fertilization and other agronomic measures on nutritional quality of crops. J. Sci. Food Agric. 88, 7-23. doi: $10.1002 /$ jsfa.3084

Weersink, A., Fraser, E., Pannell, D., Duncan, E., and Rotz, S. (2018). Opportunities and challenges for big data in agricultural and environmental analysis. Annu. Rev. Res. Econ. 10, 19-37. doi: 10.1146/annurev-resource-100516-053654

White, P. J., and Broadley, M. R. (2009). Biofortification of crops with seven mineral elements often lacking in human diets - iron, zinc, copper, calcium, magnesium, selenium and iodine. N. Phytol. 182, 49-84. doi: 10.1111/j.1469-8137.2008.02738.x

Xing, S. G., Jun, Y. B., Hau, Z. W., and Liang, L. Y. (2007). Higher accumulation of $\gamma$-aminobutyric acid induced by salt stress through stimulating the activity of diamine oxidases in Glycine max (L.) Merr. roots. Plant Physiol. Biochem. 45, 560-566. doi: 10.1016/j.plaphy.2007.05.007

Yuan, L., and Knauf, V. C. (1997). Modification of plant components. Curr. Opin. Biotechnol. 8, 227-233. doi: 10.1016/S0958-1669(97)80107-3

Zhang, Y., Butelli, E., Alseekh, S., Tohge, T., Rallapalli, G., Luo, J., et al. (2015). Multi-level engineering facilitates the production of phenylpropanoid compounds in tomato. Nat. Commun. 6:8635. doi: 10.1038/ncomms9635

Zhu, C., Naqvi, S., Gomez-Galera, S., Pelacho, A. M., Capell, T., and Christou, P. (2007). Transgenic strategies for the nutritional enhancement of plants. Trends Plant Sci. 12, 548-555. doi: 10.1016/j.tplants.2007.09.007

Zou, J., Katavic, V., Giblin, E. M., Barton, D. L., MacKenzie, S. L., Keller, W. A., et al. (1997). Modification of seed oil content and the acyl composition in the Brassicaceae by expression of a yeast sn-2 acyltransferase gene. Plant Cell 9 , 909-923. doi: 10.1105/tpc.9.6.909

Conflict of Interest Statement: The authors declare that the research was conducted in the absence of any commercial or financial relationships that could be construed as a potential conflict of interest.

Copyright (c) 2019 Roberts and Mattoo. This is an open-access article distributed under the terms of the Creative Commons Attribution License (CC BY). The use, distribution or reproduction in other forums is permitted, provided the original author(s) and the copyright owner(s) are credited and that the original publication in this journal is cited, in accordance with accepted academic practice. No use, distribution or reproduction is permitted which does not comply with these terms. 